\title{
Corporate Social Responsibility and Financial Performance: A Case Study of Jamuna Bank Limited, Bangladesh
}

\author{
Mohammad Mazibar Rahman (corresponding author) \\ Department of Accounting \\ Hajee Mohammad Danesh Science and Technology University \\ Dinajpur-5200, Bangladesh \\ E-mail: mazibar.act.hstu@gmail.com \\ Md. Mamunar Rashid \\ Associate Professor, Department of Accounting \\ Hajee Mohammad Danesh Science and Technology University \\ Dinajpur-5200, Bangladesh \\ E-mail: raselhstu@yahoo.com \\ Md. Reiazul Haque \\ Assistant Professor, Department of Accounting \\ Hajee Mohammad Danesh Science and Technology University \\ Dinajpur-5200, Bangladesh \\ E-mail: mrhaque01@gmail.com
}

Received: Sep. 26, 2014 Accepted: Nov. 4, 2014 Published: December 1, 2014

doi:10.5296/ajfa.v6i2.6358 URL: http://dx.doi.org/10.5296/ajfa.v6i2.6358

\begin{abstract}
Banking is a business which runs on the confidence and the trust of people that enables the bank to mobilize funds from various sources. The profitability of a bank always depends on
\end{abstract}




\section{Macrothink}

Asian Journal of Finance \& Accounting

ISSN 1946-052X

2014, Vol. 6, No. 2

the efficient management of fund and exploring the genuine avenues in which its resources are invested to produce the maximum income. The purpose of the study is to discover the impact of Corporate Social Responsibility (CSR) expenditure on the profitability of Jamuna Bank Ltd (JBL) which indicates the fundamental picture of the overall banking industry of Bangladesh. JBL is one of the non-government commercial banks in Bangladesh, for this study purpose CSR expenditure is taken as the independent variable and profit after tax (PAT) as the dependent variable. Required data are collected from the annual reports of JBL and Bangladesh Bank CSR review for the year 2007 to 2012 and analyzed using Ordinary least squares (OLS) model and tested the hypothesis through the student's $t$ test. The results show that there is no significant impact of CSR on PAT and therefore recommends the bank to critically evaluate its existing policy on performing CSR activities to increase profitability. For academic and industry discourse it is suggested that further study should be conducted to establish the real value, in monetary terms, how much CSR contribute to the organization's profitability.

Keywords: CSR, Bangladesh Bank, JBL, Profitability, Profit after Tax 


\section{Introduction}

Since the 1950s, CSR (Bowen, 1953) along with the related notions of corporate social responsiveness, corporate social responses (Strand, 1983), and corporate social performance (Carroll, 1979; Wood, 1991), have been the subject of many conceptualizations originating mainly from the management literature. In Bangladesh, the banking sector has a glorious history of getting engaged themselves in different kinds of social activities which is formally known as CSR like donations to different educational and social organizations, country beautification, patronizing cultural activities, health etc. But in some recent years there is tremendous growth in this involvement, because in the 2008 Bangladesh Bank guideline suggested the banks to involve in these activities in a more structured way. All banks have embraced CSR in 2013 with a decision at the highest corporate level have formed separate foundations or trusts as non-profitable institutions solely devoted to the cause of charity, social welfare and other benevolent activities towards the promotion of CSR objectives. The majority of banks in Bangladesh has committed to specified percentages of their pretax profit/net profit each year towards CSR activities. Corporate Social Responsibility (CSR) is gaining fast global acceptance as a standard to assume environmentally sustainable and socially equitable business practices. CSR then is not only a topic for business, but equally a subject for government and civil society or the NGO sector. Driving forces behind this evolution is pressure from various stakeholders (Importers, Environmentalists) while slow progress is attributed to lack of good governance, absence of strong labor unions, consumer forums and above all lack of understanding by business houses, specifically non-exporting ones, that CSR is not charity but is rather an instrumental PR investment. The role of business world-wide and specifically in the developed economies has evolved from classical 'profit maximizing' approach to a 'social responsibly' approach, where businesses are not only responsible to its stockholders but also to all of its stakeholders in a broader inclusive sense. As a member of the global economy, Bangladesh is also aware of the need to take positive initiatives to establish an image of environmentally and socially responsible businesses. However, these efforts were hardly recognized and labeled as CSR activities since most of the financial institutions have not integrated CSR in their routine operation; rather these were in the form of occasional charity or promotional activities. Bangladesh Bank will monitor CSR adoption and CSR performance of banks and financial institutions, as an additional dimension of their management performance. The banking community has responded sensibly to the call for CSR and sustainable social development. This paper in basically focused on the CSR activities of the JBL and how it is related to profitability and to what extent banks are eager to involve in these sorts of CSR activities. Banks are profit based organizations, so in this perspective they surely want to spend money in those sectors which will directly or indirectly bring money for them, so obviously there are some positive relationships between CSR and bank's profitability. The rest of the paper is structured as follows. We first present a basic framework to capture the notion of CSR as a tool in maximizing profits. In section 2, we explain the literature review and data sources we use. Section 3 highlights research objectives and section 4 explores the research methodology and model development. Finally, in section 5 and 6, we address analysis, hypothesis testing and conclusion of CSR choices. 


\section{Literature Review and Conceptual Framework}

The general signaling role of CSR was also studied by Goyal (2006). That study however is considerably different from the relative authors as it did not consider the brand-value of firms. Rather, Goyal (2006) investigated the signaling role of the CSR when firms considering FDI (Foreign Direct Investment) are interested in favorable terms. Some progressive companies in Bangladesh voluntarily provide some information with regard to social and environmental matters (Chowdhury and Chowdhury, 1996). CSR is one of the corporation's responsibilities to its stakeholder and also a voluntary contribution by a corporation to sustainable development (Crane and Matten, 2007). In addition, the view of CSR as an obligation fails to provide normative criteria to evaluate the extent to which actual business practices can or cannot be considered as socially responsible (Jones, 1995). In particular, as stated by Clarkson (1995), society is at "a level of analysis that is both more inclusive, more ambiguous and further the ladder of abstraction than a corporation itself". Clarkson (1995) argued that businesses are not responsible to society as a whole but only toward those who directly or indirectly affect or are affected by the firm's activities. This first perspective was launched by Bowen (1953), who defined CSR as the obligation "to pursue those policies, to make those decisions, or to follow those lines of action which are desirable in terms of the objectives and values of our society". The view of CSR as a social obligation has been advocated in later conceptualizations (Carroll, 1979) and contemporary marketing studies (Brown and Dacin, 1997; Sen and Bhattacharya, 2001). As emphasized by Carroll (1979), different types of social obligations can be distinguished: (a) economic obligations (be productive and economically viable), (b) legal and ethical obligations (follow the law and acknowledged values and norms), and (c) philanthropic obligations (proactively give back to society). The companies have to satisfy the divergent number of stakeholders, the credible relationship is created through CSR reporting. It improves communication with the community and other stakeholders and results in competitive advantage (Anand, 2002). Imam (2000) has conducted a survey of CSR practices in Bangladesh which shows that the CSR disclosure level is not adequate. The current voluntary system of social reporting has failed to achieve either the goal of organizational transparency or stakeholder engagement. Instead, a fair assessment is that corporations have been able to co-opt a process designed for stakeholder accountability and turn it into a process of stakeholder management (Owen et al., 2000). A growing consensus is that firms are only disclosing social and environmental information when they are faced with some type of crisis that threatens their legitimacy (Deegan, 2002). Khan and Hossain (2003) made a short study on the environmental reporting practices in the annual reports of manufacturing companies of Bangladesh. Hossain et al. (2004) identified the nature of the voluntary disclosure on human resource in the annual reports in Bangladesh though it is not mandatory from a regulatory authority. Moir (2001) believes that the CSR's big impact in business may depend on two different causes. The first reason is associated with a kind of necessary ethics and morality. As companies have the resources, it is their role to solve social problems. Holmes (1976) examined this role and came to the following conclusion: "in addition to making profits, business should help to solve social problems whether or not business helps to create those problems even if there is probably no short-run or long-run profit potential" (Holmes, 1976). The second reason for 
CSR's impact is that companies have a vested interest to apply CSR. They have discovered that CSR can be used to strengthen their position in the market. By working with CSR, companies are getting a better reputation and achieving greater loyalty among employees (Moir, 2001). Martin (2002) believes that companies today face increasing demands to implement CSR from consumers or market forces, partly due to globalization and increasing demands for corporate responsibility. Smith (2003) also argues that various corporate scandals such as Enron and WorldCom have further damaged public confidence in the economy. A further reason for the requirement of CSR has increased is the growing realization among the public that government sometimes fails to resolve social problems. In the light of globalization and mistrust of large companies, there is increasing pressure on executives and their companies to deliver wider social values (Martin, 2002). Globalization has also meant that large companies have spread their operations to countries with lower living standards than in Western countries, places where there is no democracy and developed laws. In these countries, companies have an opportunity to compensate for the lack of laws by working with CSR (Smith, 2005). The relationship between CSR and financial performance has produced mixed results with some studies concluding for a positive others negative and even others for the existence of such a relationship (McWilliams and Siegel, 2006; Margoslis, Elfenbein and Walsh, 2007). The empirical studies conducted in developed markets on the relationship between CSR and financial performance is essentially of two distinct categories (Margolis and Walsh, 2007). Most of the prior studies found a positive relationship between CSR and financial performance (Simpson and Kohers, 2002; Graves and Waddock, 1994; McGuire et al., 1988). Moskowitz (1972) found a positive relationship between socially responsible business practices and corporate equity returns. Policies, strategies and programmes that are associated with social activities can be used to indicate the level of CSR's commitment of an organization. Organizations too, need to meet the customer's demand and expectations. As to maintain good relationship and attract more customers, enterprises are taking initiatives to fulfill the demand of providing such information. Employees who feel protected and appreciated will increase their productivity in production and thus, will achieve economies of scale.

\section{Research Objectives}

The general objective of this study is to examine the effect of CSR expenditure on JBL's profitability. But specifically, the study also sought to achieve the following objectives:

i. To find out how JBL carries its CSR.

ii. To investigate whether CSR guarantees the strong profitability linkage.

\section{Methodology and Model Development}

Secondary data were the chief source of information for the study. The study used the annual reports of JBL. Data used include CSR expenditure and PAT for the period of 2007-2012. An extensive literature reviewed to understand the concept of CSR and the relationship between CSR and financial performance of banking business. Data relating to cost/investment/expenditure for the bank on CSR and PAT were used to construct an OLS 


\section{Macrothink}

Asian Journal of Finance \& Accounting

ISSN 1946-052X

2014, Vol. 6, No. 2

model of regression to which was analyzed to assess the impact as well as test the hypothesis of the study; if there is a relationship and the extent of the relationship, if any, between the independent variable (CSR expenditure) and the dependent variable (PAT). Pearson product moment correlation coefficient (r) was used to determine the nature of relationship, coefficient of determination $\left(r^{2}\right)$ and adjusted $r^{2}$ to conclude on the power of independent variables in explaining the variations of dependent variable. The formulated hypothesis was experienced by using the student's $t$ test at the $5 \%$ level of significance.

\subsection{Model Development}

$\mathrm{P}_{\mathrm{t}}=\alpha_{0}+\beta_{1} \mathrm{CSR}_{\mathrm{t}}+\dot{\varepsilon}$

This study also attempted to use the Pearson correlation analysis method; this is consistently in line with previous studies to understand the CSR and Profitability link and its relational degree and direction.

\subsection{CSR and PAT}

Table 1 represented the total amount of CSR which JBL spent through the year of 2007 to 2012. It shows that the increasing value of CSR in every year also increases the profit of the company.

Table 1. CSR and Profitability of JBL for year 2007 to 2012

\begin{tabular}{|l|l|l|l|}
\hline S1 No. & Year & *CSR (Tk.) & *PAT (Tk.) \\
\hline 1 & 2007 & $142,17,894$ & $891,10,000$ \\
\hline 2 & 2008 & $14,51,338$ & $4764,30,000$ \\
\hline 3 & 2009 & $45,76,813$ & $9231,23,207$ \\
\hline 4 & 2010 & $170,00,000$ & $10663,69,649$ \\
\hline 5 & 2011 & $552,00,000$ & $13301,93,325$ \\
\hline 6 & 2012 & $290,20,000$ & $10453,96,736$ \\
\hline
\end{tabular}

*Source: Bangladesh Bank CSR Review and JBL Annual report 2007-2012.

\section{Discussion and Analysis}

\subsection{Statement of Hypothesis}

$H_{0}$ : There is no significant effect of CSR expenditure on JBL's Profitability. $H_{1}$ : There is a significant effect of CSR expenditure on JBL's Profitability.

\subsection{Correlation Coefficient}

Pearson product moment correlation is denoted by $r$. $r$ which stands for the co-efficient of correlation is defined below as: 
Table 2. Mean value calculation of CSR and PAT

\begin{tabular}{|l|l|l|l|l|l|}
\hline Year & $\begin{array}{l}\text { CSR (X)/ } \\
\text { Tk. } \\
\text { Millions) }\end{array}$ & $\begin{array}{l}\text { PAT (Y)/(Tk. } \\
\text { Millions) }\end{array}$ & $(\boldsymbol{X}-\overline{\boldsymbol{X}})$ & $(\boldsymbol{Y}-\overline{\boldsymbol{Y}})$ & $(\boldsymbol{X}-\overline{\boldsymbol{X}})(\boldsymbol{Y}-\overline{\boldsymbol{Y}})$ \\
\hline 2007 & 14.217894 & 89.110000 & -6.026447 & -732.660486 & 4415.33946452624 \\
\hline 2008 & 1.451338 & 476.430000 & -18.793003 & -345.3404862 & 14548.17939 \\
\hline 2009 & 4.576813 & 923.123207 & -15.667528 & 101.352721 & -1587.946574 \\
\hline 2010 & 17.000000 & 1066.369649 & -3.244341 & 244.599163 & -793.5630509 \\
\hline 2011 & 55.200000 & 1330.193325 & 34.955659 & 508.422839 & 17772.25547 \\
\hline 2012 & 29.020000 & 1045.396736 & 8.7756591 & 223.6262498 & 8452.883842 \\
\hline Mean & 20.244341 & 821.7704862 & & & Total =28258.5379 \\
\hline
\end{tabular}

The co-efficient of correlation is independent of the scale used if we divide the term $\sum(X-\bar{X})(Y-\bar{Y})$ by the sample standard deviation. It is also made independent of the sample size, and bounded by the values +1.00 and -1.00 if we divide by (n-1).

Correlation Coefficient

$$
\begin{aligned}
r & =\frac{28258.5379}{(6-1)(19.721)(454.8967)} \\
& =0.6300
\end{aligned}
$$

Coefficient of determination, $\quad r^{2}=0.3969$

Adjusted

$$
\mathrm{r}^{2}=0.2375
$$

The calculated value of $r$ suggests that there is a direct relationship between CSR and profitability for the JBL. However, the $r^{2}$ value points that the association is not so strong. CSR can only explain $23.75 \%$ of the variation in profitability.

\section{3 t test for the coefficient of Correlation:}

At the 0.05 level of significance, the decision rule state that if the computed $t$ falls in the area between +2.776 and -2.776 the null hypothesis can not be rejected.

$$
\begin{aligned}
t & =\frac{0.6300 \sqrt{6}-2}{\sqrt{1}-(0.6300)^{2}} \\
& =\frac{1.26}{0.7765} \\
& =1.6226
\end{aligned}
$$

$\mathrm{p}=0.18$

The computed $t$ value is 1.6226 which falls within the critical limit. Additionally, the calculated $p$ value is higher than the predetermined level of significance. Thus at the $5 \%$ level of significance, the null hypothesis that there is no significant effect of CSR expenditure on JBL's profitability can't be rejected. 
5.4 Liner Regression Analysis:

$$
\begin{gathered}
\mathrm{P}_{\mathrm{t}}=\alpha_{0}+\beta_{1} \mathrm{CSR}_{\mathrm{t}}+\dot{\varepsilon} \\
\text { Where, } \beta_{1}=\mathrm{r}\left(\frac{s_{y}}{S_{x}}\right) \\
\beta_{1}=0.6300\left(\frac{454.8967}{19.721}\right) \\
=14.531 \\
\alpha_{0}=821.7705-(14.531 * 20.2444) \\
=527.599
\end{gathered}
$$

The value of calculating $r$ indicates that the CSR and financial performance of JBL have a positive direct relationship. Thus, the regression equation is $\mathrm{P}_{\mathrm{t}}=527.599+14.531 \mathrm{CSR}_{\mathrm{t}}$ So if JBL spent 14.218 million CSR in 2007, then expected PAT would be 734.209 million. The $\alpha_{0}$ value of 527.599 is the point where the equation crosses the PAT value. A literal translation is that if there was no CSR made by JBL then the amount of PAT estimated 527.599.

\section{Conclusion}

Nowadays, the concept of CSR has become more and more common in business practices and customers who expect companies to be socially responsible although the initiative may not work for all types of organization. Hence designing CSR scheme requires careful planning and implementation mechanism by the high level management. Consequently, the study is undertaken to get an idea about the CSR activities performed by JBL and its impact on profitability. Taking into account the results, the study shows that there is no significant effect of CSR on profitability for JBL throughout the years 2007 to 2012. As a consequence, the bank is suggested that it should be careful in designing activities concerning CSR. Future research in this area could proceed in a number of directions. Firstly, more extensive studies are needed to explore the causal mechanisms linking CSR to profitability and to determine whether or not those relationships hold consistently over time. Secondly, it is also important to position the timing in the relationship, since it would be valuable to investigate and to ascertain how long it takes for the impact of CSR on financial performance to be revealed. Finally, the reliability of the CSR data should be determined, as the sources have significant differences regarding how to evaluate the CSR performance of a firm.

\section{Acknowledgement}

This study is based on a part of my MBA thesis conducted at the Department of Accounting of the Hajee Mohammad Danesh Science and Technology University. I also gratefully appreciate 
my supervisor Md. Mamunar Rashid, Associate Professor, Department of Accounting, Hajee Mohammad Danesh Science and Technology University for his nice supervision and guideline.

\section{References}

Anand, V. (2002). Building Blocks of Corporate Reputation- Social Responsibility Initiatives. Corporate Reputation Review, 5, 71-74. http://dx.doi.org/10.1057/palgrave.crr.1540165

Bowen, H. R. (1953). Social Responsibilities of the Businessman. Harper \& Row, NewYork.

Brown, T. J. and Peter A. Dacin. (1997). The Company and the Product: Corporate Associations and Consumer Product Responses. Journal of Marketing, 61, 68-84. http://dx.doi.org/10.2307/1252190

Carroll, Archie B. (1979). A Three-Dimensional Conceptual Model of Corporate Performance. Academy of Management Review, 4 (4), 497-505. http://dx.doi.org/10.2307/257850

Chowdhury A. I. \& Cowdhury A. K. (1996). Corporate Social Accounting: Do We Really Need It? The Bangladesh accountant, 11, 90-100.

Clarkson M. E. (1995). A Stakeholder Framework for Analyzing and Evaluating Corporate Social Performance. Academy of Management Review, 20 (1), 92-117. http://dx.doi.org/10.5465/AMR.1995.9503271994

Crane A., Matten D. (2007). Corporate Social Responsibility: theories and concepts of corporate social responsibility. Sage Publications, London. http://dx.doi.org/10.4135/9781446261194

Deegan, C. (2002). The Legitimizing Effect of Social and Environmental Disclosures-A Theoretical Foundation. Accounting, Auditing \& Accountability Journal, 15(3), 282-311. http://dx.doi.org/10.1108/09513570210435852

Goyal A. (2006). Corporate Social Responsibility as a Signaling Device for FDI. Internal Journal of the Economics of Business, 13(1), 145-163. http://dx.doi.org/10.1080/13571510500520077

Graves, S. B. and Waddock, S. A. (1994). Institutional Owners and Corporate Social Performance. Academy of Management Journal, 37(4), 1034-1046. http://dx.doi.org/10.2307/256611

Holmes, S. L. (1976). Executive Perceptions of Corporate Social Responsibility. Business Horizons, 19(3), 34-40. http://dx.doi.org/10.1016/0007-6813(76)90049-5

Hossain, D. M., Khan, A. R. \& Yasmin, I. (2004). The Nature of Voluntary Disclosure on Human Resource in Annual Reports of Bangladesh Companies. Dhaka University Journal of Business Studies, 25 (1), 221-231.

Imam, S. (2000). Corporate Social Performance Reporting in Bangladesh. Managerial Auditing Journal, 15 (3), 12-13. http://dx.doi.org/10.1108/02686900010319384 
Jones, T. M. (1995). Instrumental Stakeholder Theory: A Synthesis of Ethics and Economics. Academy of Management Review, 20(2), 404-437. http://dx.doi.org/10.5465/AMR.1995.9507312924

Khan, A. R. \& Hossain, D. M. (2003). Environmental Reporting as a Corporate Social Responsibility: A Study on the Annual Reports of Manufacturing Companies in Bangladesh. The Bangladesh Accountant, 75, 87-101.

Margolis, J., Elfenbein, H. and Walsh, J. (2007). Does It Pay To Be Good? A Meta Analysis and Redirection of Research on the Relationship between Corporate Social and Financial Mimeo. Harvard Business School review, Boston.

Martin, R. (2002). The Virtue Matrix: Calculating the Return on Corporate Social Responsibility - Shareholder Value Versus Corporate Responsibility. Harvard Business Review, 80(3).

McWilliams and Siegel. (2006). Corporate Social Responsibility: Strategic Implications. Journal of Management Studies, 43(1), 1-18. http://dx.doi.org/10.1111/j.1467-6486.2006.00580.x

McGuire, Sundgren and Schneeweis. (1988). Corporate Social Responsibility and Firm Financial Performance. Academy of Management Journal, 31(4), 854-872. http://dx.doi.org/10.2307/256342

Moir, L. (2001). What Do We Mean by Corporate Social Responsibility? Corporate Governance, 1(2), 16-22. http://dx.doi.org/10.1108/EUM0000000005486

Moskowitz, M. (1972). Choosing Socially Responsible Stocks. Business and Society Review, 1, 71-75. http://dx.doi.org/10.1016/0361-3682(92)90015-K

David L. Owen, Tracey A. Swift, Christopher Humphrey \& Mary Bowerman. (2000). 'The New Social Audits: Accountability, Managerial Capture or the Agenda of Social Champions?' European Accounting Review, 9(1), 81-99. http://dx.doi.org/10.1080/096381800407950

Sen Sankar and C. B. Bhattacharya. (2001). Does Doing Good Always Lead to Doing Better? Consumer Reactions to Corporate Social Responsibility. Journal of Marketing Research, 38, 225-243. http://dx.doi.org/10.1509/jmkr.38.2.225.18838

Simpson, W. G. and Kohers, T. (2002). The Link between Corporate Social and Financial Performance: Evidence from the Banking Industry. Journal of Business Ethics, 35(2), 97-109. http://dx.doi.org/10.1023/A:1013082525900

Smith, N. C. (2003). Corporate Social Responsibility: Whether or How? California Management Review, 45 (4), 52-76. http://dx.doi.org/10.2307/41166188

Smith, N. C. (2005). Responsibility Inc. Business Strategy Review, 16, 62-65.

Strand, R. (1983). A Systems Paradigm of Organizational Adaptations to the Social Environment. Academy of Management Review, 8(1), 90-96. http://dx.doi.org/10.5465/AMR.1983.4287703 


\section{Macrothink}

Wood, Donna J. (1991). Corporate Social Performance Revisited. Academy of Management Review, 16 (4), 691-718. http://dx.doi.org/10.5465/AMR.1991.4279616

Math Formula

\section{Correlation Coefficient}

$$
\mathrm{r}=\frac{\sum(X-\bar{X})(Y-\bar{Y})}{(n-1) S_{x} S_{y}}
$$

Where:

$\mathrm{r}=$ Pearson's Product Moment correlation

$\mathrm{X}=$ Independent variable (Corporate Social Responsibility)

$\bar{X}=$ Mean of independent variable (Corporate Social Responsibility)

$\mathrm{Y}=$ Dependent variable (Profitability)

$\bar{Y}=$ Mean Dependent variable (Profitability)

II. Coefficient of Determination:

$$
r^{2}=\frac{\sum(w-3)^{2}}{\sum(w-3)^{2}}
$$

III. $t$ test for the coefficient of Correlation

$$
\mathrm{t}=\frac{r \sqrt{n}-2}{\sqrt{1}-r^{2}} \quad \text { with } \mathrm{n}-2 \text { degree of freedom. }
$$

\section{Liner Regression}

$$
\mathrm{P}_{\mathrm{t}}=\alpha_{0}+\beta_{1} \mathrm{CSR}_{\mathrm{t}}+\dot{\varepsilon}
$$

